\title{
Specification of the Conjugative Pili and Surface Mating Systems of Pseudomonas Plasmids
}

\author{
By DAVID E. BRADLEY \\ Faculty of Medicine, Memorial University of Newfoundland, St. John's, Newfoundland, \\ Canada AlB 3 V6
}

(Received 4 March 1983)

\begin{abstract}
Conjugative pili were identified for representative Pseudomonas plasmids of incompatibility groups P-2, P-3, P-5, P-7, P-8, P-10, P-11, and P-13, pili for groups P-1 and P-9 having already been described in detail. FP5 pili (unclassified) were also found. In most cases pili could be characterized by electron microscopy as rigid or flexible. The majority of Pseudomonas plasmids transferred significantly better on a surface than in a liquid. Examples of all incompatibility groups were tested.
\end{abstract}

\section{INTRODUCTION}

Conjugative pili have been identified for all plasmid incompatibility (Inc) groups in Escherichia coli K12 (Bradley, $1980 a, b$ ). Electron microscopy revealed that they fell into three morphological categories : thin $(6 \mathrm{~nm})$ flexible, thick $(9 \mathrm{~nm})$ flexible, and rigid. The type of pilus influenced the optimum mating environment (liquid or surface) of the plasmid, three conjugation systems being specified (Bradley et al., 1980): surface obligatory (surface transfer $>2000$ times better than liquid transfer), surface preferred (surface transfer $45-450$ times better than liquid transfer), and universal (equal transfer in both environments). For Pseudomonas species, some conjugative pili have been identified (Bradley, 1974, 1981), but optimum plasmid mating environments have not been specified.

Like E. coli K12 plasmids, those of Pseudomonas are classified by incompatibility, groups IncP-1 to IncP-13 being recognized (Jacoby, 1977, 1980; Jacoby \& Matthew, 1979; G. A. Jacoby, personal communication). IncP-4 and IncP-6 plasmids are not self-transmissible. IncP-1 pili, which are synthesized constitutively (in large numbers), are well-characterized as thin rigid rods (Bradley \& Chaudhuri, 1980). Thick flexible pili are determined constitutively by the IncP-9 degradative plasmid TOL in its wild-type Pseudomonas putida host (Bradley \& Williams, 1982). Pili for Rms148 (IncP-7) and R91.5 (IncP-10) have been provisionally identified (Bradley, 1981). The present objective has been to identify conjugative pili for as many additional Pseudomonas plasmids as possible, and also to confirm the rigid or flexible form of the known pili. In addition, an attempt has been made to correlate pilus type with possible surface mating systems.

\section{METHODS}

Bacterial strains and plasmids. 'Bald' plasmid host strains were E. coli $\mathrm{K} 12$ strain JE2571 (leu thr str fla pil) (Bradley, 1980a), Pseudomonas aeruginosa PAO1150.1 ( la pil) (Bradley, 1980c), Pseudomonas putida PaW340.3 (trp str fla) (Bradley \& Williams, 1982); P. putida does not synthesize somatic pili. In addition, P. aeruginosa strain 280 (Bryan et al., 1973), which was available with various nutritional markers, was used with R931. Rifampicinresistant derivatives of these strains were used for the temporary derepression method (see below). Pseudomonas aeruginosa strain PU1, which carries plasmid FP2 (OT15 in Loutit et al., 1968), was used to illustrate filamentous objects which resembled pili. Most plasmids were originally supplied in P. aeruginosa strain PU21 (ilv leu str rif) (Jacoby \& Matthew, 1979), being transferred to a more suitable 'bald' host later. The plasmids used are listed and 
Table 1. Plasmids used and the morphology of their conjugative pili

\begin{tabular}{|c|c|c|c|c|c|}
\hline Inc group & Plasmid & $\begin{array}{l}\text { Resistance and other } \\
\text { phenotypic markers* }\end{array}$ & $\begin{array}{c}\text { Pilus } \\
\text { morphology } \dagger\end{array}$ & Aggregation $\ddagger$ & References $\S$ \\
\hline P-1 & RP1 & $\mathrm{Cb} \mathrm{Km} \mathrm{Tc}$ & Rigid & + & 1,2 \\
\hline P-2 & R931 & $\mathrm{Sm} \mathrm{Tc} \mathrm{Hg} \mathrm{Te}$ & Rigid & - & 3 \\
\hline $\mathrm{P}-2$ & CAM & $\mathrm{Cam}^{+} \mathrm{Te}$ & Rigid & $?$ & 4 \\
\hline P-3 & RIP64 & $\mathrm{Cb} \mathrm{Cm} \mathrm{Gm} \mathrm{Su} \mathrm{Tm} \mathrm{Hg}$ & Flexible? & $?$ & 5 \\
\hline P-5 & Rms 163 & $\mathrm{Cm} \mathrm{Su} \mathrm{Tc}$ & Flexible? & $?$ & 6 \\
\hline P-7 & Rmsl48 & $\mathrm{Sm}$ & Rigid & - & 6 \\
\hline P-8 & FP2 & $\mathrm{Hg}$ & Flexible & - & 7 \\
\hline P-9 & $\mathrm{R} 2$ & $\mathrm{Cb} \mathrm{Km} \mathrm{Sm} \mathrm{Su}$ & Flexible & $?$ & 8 \\
\hline P-10 & R91.5 & $\mathrm{Cb}$ & Rigid & + & 9 \\
\hline P-11 & RP1-1 & $\mathrm{Cb}$ & Rigid & - & 6,10 \\
\hline P-12 & R716 & $\mathrm{Sm} \mathrm{Hg}$ & $?$ & $?$ & 3 \\
\hline P-13 & pMG26 & $\mathrm{Cb} \mathrm{Cm} \mathrm{Gm} \mathrm{Km} \mathrm{Sm} \mathrm{Su} \mathrm{Tm}$ & Flexible & + & 11 \\
\hline$?$ & FP5 & $\mathrm{Hg}$ & Flexible & $?$ & 12 \\
\hline
\end{tabular}

* $\mathrm{Cb}$, carbenicillin; $\mathrm{Cm}$, chloramphenicol; Gm, gentamicin; Km, kanamycin; Sm, streptomycin; Su, sulphonamide; $\mathrm{Tc}$, tetracycline; $\mathrm{Tm}$, tobramycin; $\mathrm{Hg}$, mercury; $\mathrm{Te}$, tellurium; $\mathrm{Cam}^{+}$, camphor metabolizing ability.

$\uparrow$ ?, too few pili to be certain of morphology, probable category given.

$\ddagger+$, aggregation; - , no aggregation; ?, insufficient pili (see Methods).

$\S$ References: 1, Grinsted et al. (1972); 2, Bradley \& Chaudhuri (1980); 3, Bryan et al. (1973); 4, Rheinwald et al. (1973); 5, Witchitz \& Gerbaud (1972); 6, Jacoby (1977); 7, Holloway et al. (1971); 8, Kawakami et al. (1972); 9, Chandler \& Krishnapillai (1977); 10, Lowbury et al. (1969); 11, Jacoby (1980); 12, Matsumoto \& Tazaki (1973).

II Thin and thick flexible pili were found. Both aggregated.

referred to in Table 1, further references being given by Jacoby \& Shapiro (1977). In addition, R91 (Chandler \& Krishnapillai, 1977), and TOL ::Tn401 (Benson \& Shapiro, 1978) derived from TOL (Williams \& Murray, 1974; Wong \& Dunn, 1974), were used.

Media, culture methods, matings. Oxoid tryptone soya broth or BBL Brain Heart Infusion Broth were used, $2 \%$ (w/v) agar being added for plates. Incubation was at $37^{\circ} \mathrm{C}$, except for $P$. putida $\mathrm{PaW} 340.3$ and $P$. aeruginosa strains carrying the CAM or TOL plasmids when $30^{\circ} \mathrm{C}$ was used. Plasmid transfer from $P$. aeruginosa PU21 to PAO1150.1 was by conventional plate mating using M9 minimal salts medium supplemented with $0.25 \%(\mathrm{w} / \mathrm{v})$ glucose for selection of the prototrophic recipient. Drug concentrations used for plasmid selection are listed in Table 2. Sometimes, transconjugant-selecting plates were made with BBL Brain Heart Infusion agar containing $100 \mu \mathrm{g}$ rifampicin $\mathrm{ml}^{-1}$ together with an appropriate plasmid-selecting drug. Comparative plate and broth matings were done isogenically using strain PAO1150.1 containing the plasmid, with its rifampicin-resistant derivative as recipient. This strain had no surface appendages which might affect the transfer frequencies obtained. The method was that of Bradley et al. (1980), at least two experiments being done, and average values being given in the Results.

Electron microscopy. Bacteria were usually grown by the temporary derepression method (Bradley, 1980a), which provided confluent transconjugant growth on a nutrient plate containing a plasmid-selecting drug and $100 \mu \mathrm{g}$ rifampicin $\mathrm{ml}^{-1}$ for donor counterselection. Bacteria from these plates, and also those from non-selective nutrient plates incubated overnight (used for derepressed plasmids), were mounted for electron microscopy as described by Bradley $(1980 a, b)$. Immune electron microscopy was done by the grid-labelling method of Lawn (1967) using antiserum to pure somatic $P$. aeruginosa PAOl pili kindly supplied by $\mathrm{Dr} W$. Paranchych. Negative staining was with $1 \%(\mathrm{w} / \mathrm{v})$ sodium phosphotungstate solution. Pilus thickness was not usually measured since it varied with local negative staining conditions and was not meaningful save for the comparison of two different types of pilus adjacent to one another.

The aggregation of pili was assessed by observing whether or not they formed bundles as in Fig. 4, or when fewer were present, whether or not they formed pairs (Fig. 16). A lack of aggregation could not be demonstrated with low densities of pili on the electron microscope specimen support grid. Examples of a few areas where several detached pili were close together with no pairs or bundles were required (Fig. 9).

\section{RESULTS}

\section{Pilus-like structures produced by cultures of Pseudomonas species}

The search for conjugative pili was hampered by the production of spurious structures, some of which are illustrated here so that others may recognize them. Filamentous metabolic 

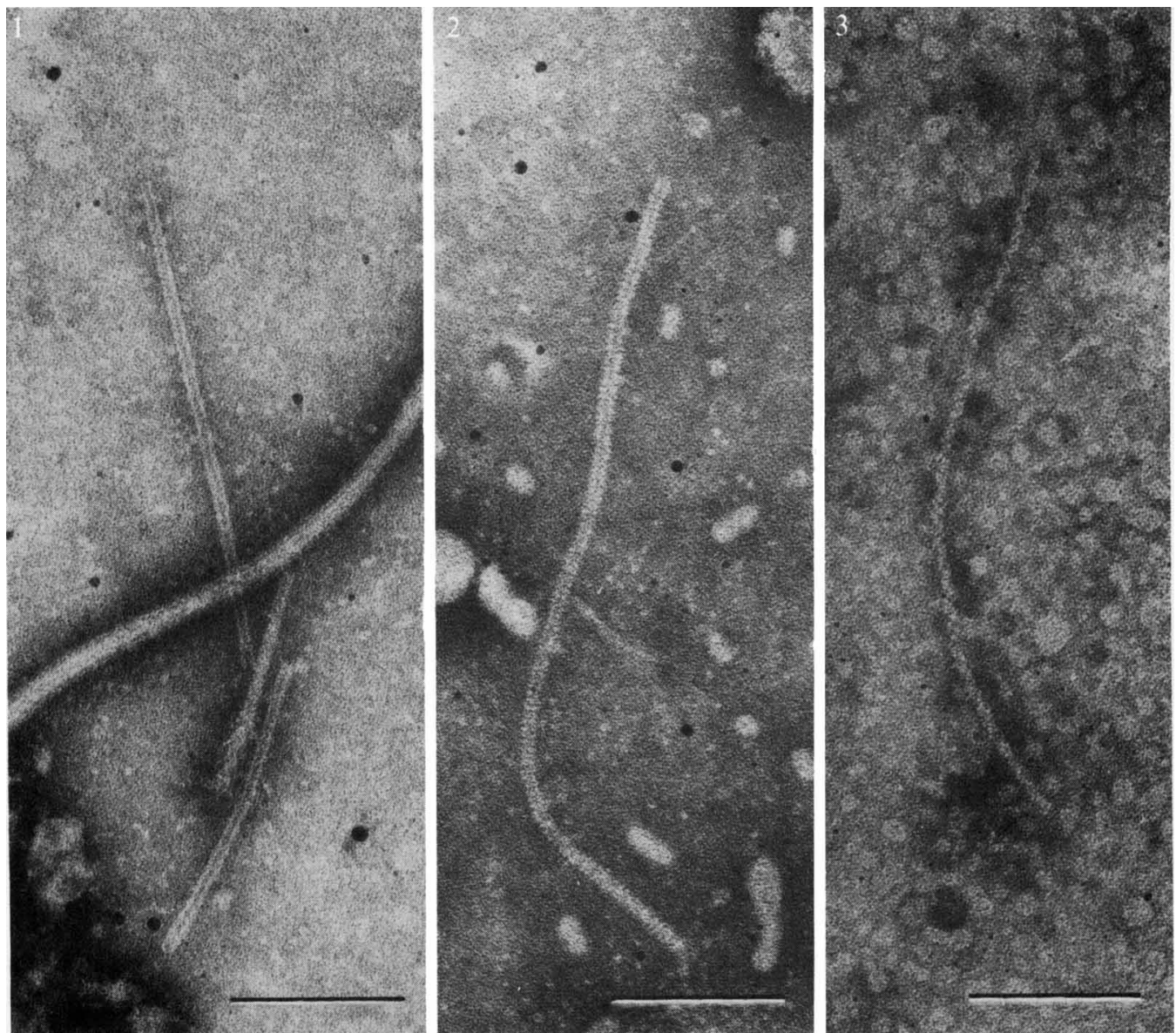

Fig. 1. Polymerized bacteriocin core protein from $P$. aeruginosa strain PU1. The bar marker represents $100 \mathrm{~nm}$.

Fig. 2. Flexible bacteriocin-like structure from $P$. aeruginosa strain PU1. The bar marker represents $100 \mathrm{~nm}$.

Fig. 3. Pilus-like filament with faint helical structure from $P$. aeruginosa strain PAO1150.1. Structures in Figs 1-3 were found in most strains of $P$. aeruginosa whether or not a plasmid was carried. The bar marker represents $100 \mathrm{~nm}$.

products, which were easily identified by their variable thickness and high contrast (not illustrated), were produced by $P$. aeruginosa and $P$. putida (Bradley \& Williams, 1982). The following objects found in association with some lines of $P$. aeruginosa had to be reliably distinguished from conjugative pili. Polymerized aeruginocin core protein (Fig. 1), associated with a contractile bacteriocin in the form of a headless phage tail (Bradley, 1967), closely resembled rigid pili but was thinner and always had a hollow appearance. Flexible aeruginocinlike structures (Fig. 2) were distinguishable by cross-striations visible at high magnification. Pseudomonas aeruginosa strain PU1, which was used to illustrate these structures, carried plasmid FP2 and synthesized P-8 pili as well (see below). A thinner pilus-like filament (Fig. 3) had a less obvious periodic structure. Pseudomonas aeruginosa somatic pili were thinner than most conjugative pili (not illustrated; see Bradley, 1972). Although the strains used here did not normally synthesize them, when production did occur, identification was made by immune electron microscopy (see Methods). 


\section{Morphology of conjugative pili determined by Pseudomonas plasmids}

Table 1 summarizes the results of an electron microscopic survey of $P$. aeruginosa strain PAO1150.1 containing plasmids representing each Pseudomonas incompatibility group. Most conjugative pili could be recognized as being rigid or flexible with reasonable certainty (Bradley, $1980 \mathrm{~b}$ ). Whether or not pili aggregated could not always be determined because sometimes too few pili were produced (Table 1). A difference in the aggregation characteristics (see Methods) of two morphologically similar types of pili can distinguish them since a chemical difference in the pilin (pilus protein) is indicated (Bradley, 1980a).

IncP-1 pili are typified by those of RP1 which were synthesized in very large numbers (Fig. 4) by $E$. coli K12 strain JE2571 (RP1). Pseudomonas aeruginosa PAO1150.1 (RP1) produced comparatively few pili, aggregates of two or three being the rule. P-1 pili were about $8 \mathrm{~nm}$ thick with one pointed end, a feature not previously noted (Fig. 5).

P-2 is the largest and commonest incompatibility group. Pili of the repressed plasmid R931 were sought using $P$. aeruginosa strain 280 as host (Bryan et al., 1973). In one experiment only, the temporary derepression method of growth gave many rigid rods (Fig. 6), the shorter ones probably being fragments of longer ones. Plasmid transfer was poor, and only one out of several repeat experiments produced a few pili. The plasmid CAM was therefore studied in host strain $P$. putida $\mathrm{PaW} 340.3$ using tellurium plus streptomycin selection for the temporary derepression method. One or two rigid rods similar to R931 pili were found on each electron microscope specimen support grid square (not illustrated).

IncP-3 plasmids can be transferred to $E$. coli (Witchitz \& Chabbert, 1971) where they are classified as IncC and determine thick flexible pili (Bradley, 1980a). Pseudomonas aeruginosa PAO1150.1 (RIP64) gave no pili by the temporary derepression method using either mercury or gentamicin for selection. However, a very few were found with cultures on non-selective plates incubated either overnight or for $4 \mathrm{~h}$. Only five pili were counted on three support grids, each being examined in the electron microscope for about $15 \mathrm{~min}$. P-3 pili were easily recognizable and were probably of the thick flexible kind (Fig. 7); they could not be confused with any other structure.

Rms163 is representative of incompatibility group P-5. Despite reasonable transfer when grown by the temporary derepression method, strain PAO1 150. 1 (Rms 163) provided only about five pili in several preparations. These were probably of the thick flexible type (Fig. 8).

Rms148 (IncP-7) is naturally derepressed for transfer and an overnight culture on a nonselective plate gave many non-aggregating short nail-like rods (Fig. 9). A few long pili allowed their identification as rigid (not illustrated).

Incompatibility group P-8 consists of the single important plasmid FP2, which mobilizes the $P$. aeruginosa chromosome. Figure 10 shows that its pili, synthesized by PAO1150.1 (FP2), are thick and flexible with a terminal structure, 1-4 being found on each specimen support grid square using the temporary derepression method (mercury selection). They did not aggregate. Strain PU1, which also carries FP2, synthesized similar pili (not illustrated).

While P-9 pili, exemplified by those of the TOL plasmid, have been described in detail elsewhere (Bradley \& Williams, 1982), those of another plasmid in the group were sought for comparison. R2 was the only one of several different repressed plasmids (TOL is naturally derepressed) that provided pili; only ten were found in several different preparations (temporary derepression method, carbenicillin selection). They were thick and flexible (Fig. 11) like TOL pili.

$\mathrm{P}-10$ is the only incompatibility group containing a plasmid that has been made derepressed in the laboratory. R91 .5 (parent R91) determined very numerous thick rigid pili which aggregated. They had sharp-pointed ends (Fig. 12), and what was presumed to be a basal structure sometimes in the form of a ring (Fig. 13).

Incompatibility group P-11 contains the plasmid RPI-1 that transferred very well (see Table 2). However, it did not determine conjugative pili constitutively, only one or two being found on each specimen support grid square. Longer pili (not illustrated) were identified as rigid, but the majority were short non-aggregating nail-like structures (Fig. 14). 

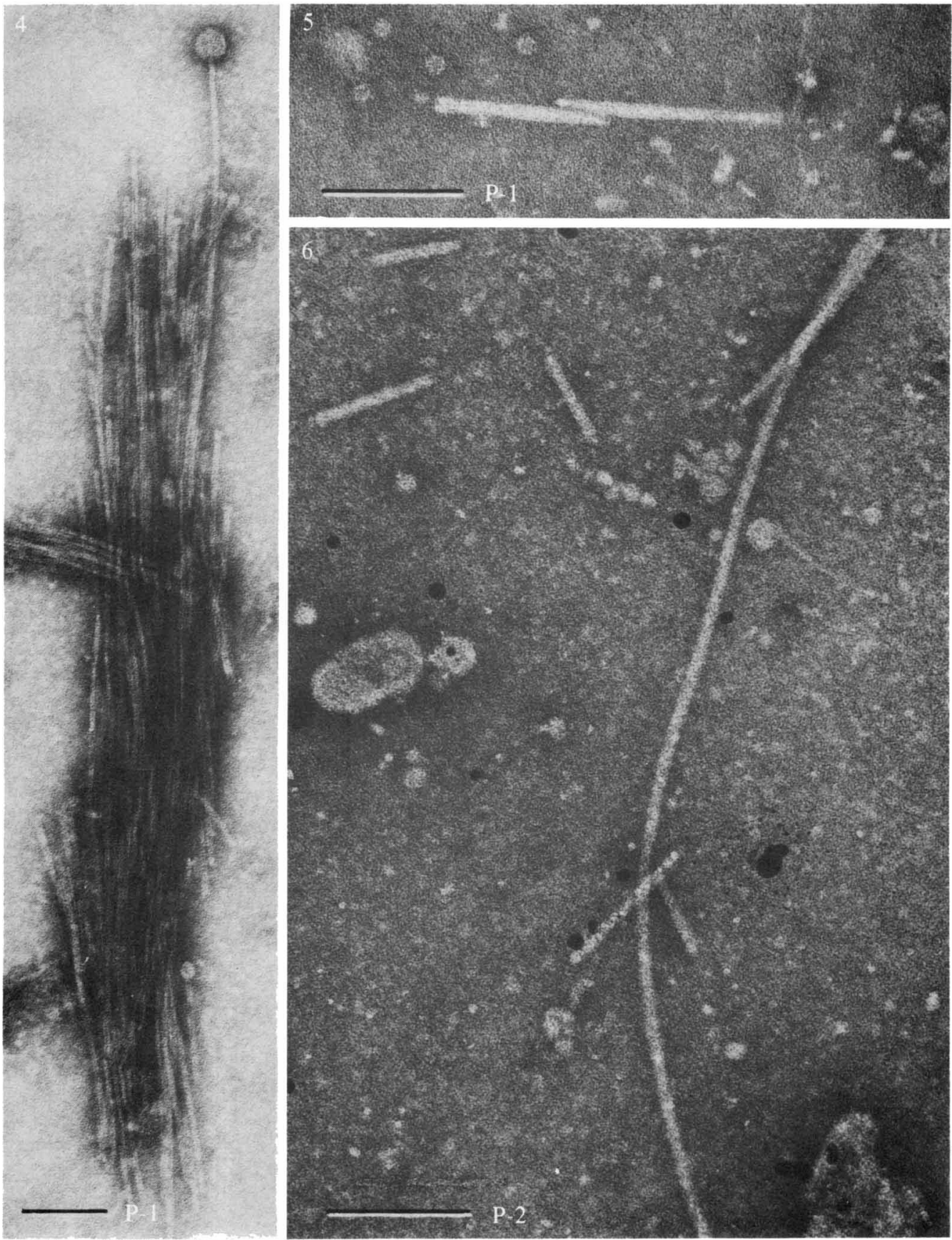

Fig. 4. Escherichia coli K12 strain JE2571 (RPI) synthesized these large aggregates of P-1 pili in considerable quantity. The bar marker represents $100 \mathrm{~nm}$.

Fig. 5. Pseudomonas aeruginosa strain PAO1150.1 (RP1) synthesized fewer conjugative pili than $E$. coli, small aggregates being found. P-1 pili have been described before (Bradley, 1974; Bradley \& Chaudhuri, 1980) but are included here for completeness. The bar marker represents $100 \mathrm{~nm}$.

Fig. 6. P-2 pili determined by R931 in host strain $P$. aeruginosa 280 . The bar marker represents $100 \mathrm{~nm}$. 

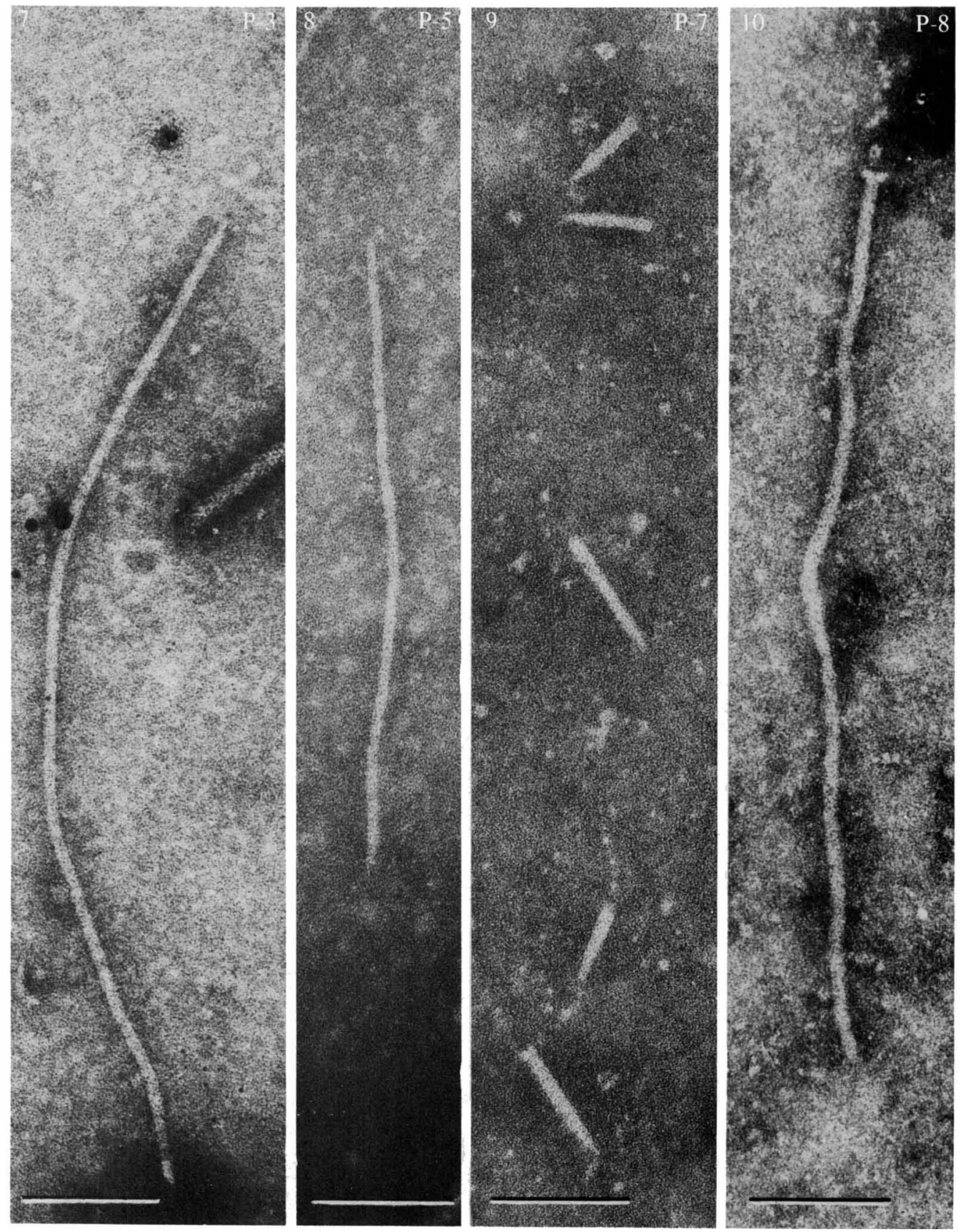

Fig. 7. Only about five P-3 pili were found in an extensive search using P. aeruginosa strain PAO1150.1 (RIP64), but they were unmistakable. The bar marker represents $100 \mathrm{~nm}$.

Fig. 8. Again only five P-5 pili were found using strain PAO1150.1 (Rmsl63), and these were less obvious than P-3 pili. The bar marker represents $100 \mathrm{~nm}$.

Fig. 9. PAO1150.1 (Rms148) synthesized many short rods. The bar marker represents $100 \mathrm{~nm}$.

Fig. 10. P-8 pili of FP2 (host PAO1150.1) were thick, flexible, and quite numerous. The bar marker represents $100 \mathrm{~nm}$. 

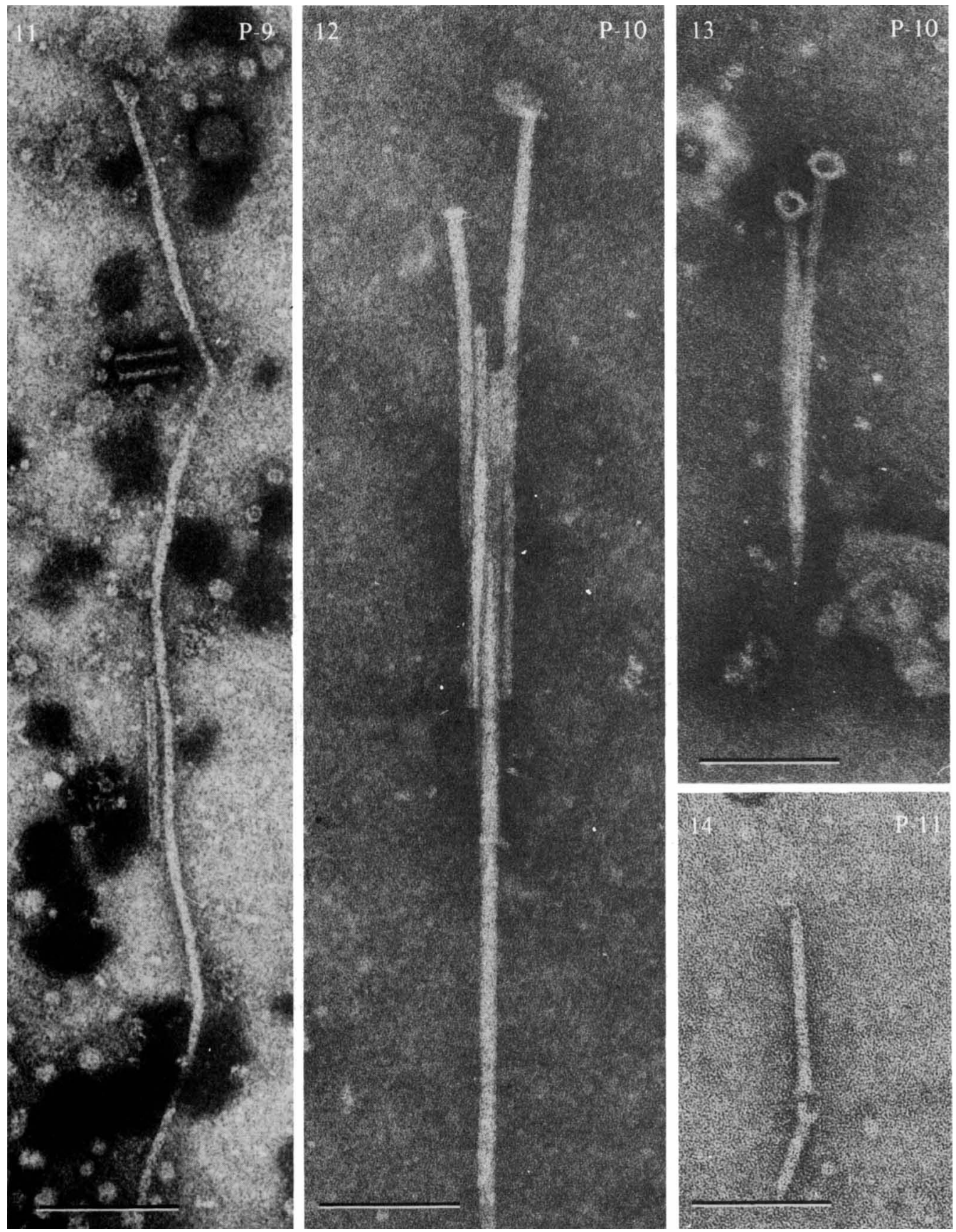

Fig. 11. Pseudomonas aeruginosa strain PAO1150.1 (R2) only produced very few pili (P-9) which were thick flexible. The bar marker represents $100 \mathrm{~nm}$.

Fig. 12. IncP-10 plasmid R91.5 is derepressed for transfer and determined many rigid pointed rods in host strain PAO1150.1. The bar marker represents $100 \mathrm{~nm}$.

Fig. 13. P-10 pili often had ring-like structures at one end, probably representing the pilus base. The bar marker represents $100 \mathrm{~nm}$.

Fig. 14. PAO1150.1 (RP1-1) determined rigid pili some of which were longer than the short rods illustrated (IncP-11). The bar marker represents $100 \mathrm{~nm}$. 
Table 2. Comparison of transfer frequencies for surface and liquid matings*

\begin{tabular}{|c|c|c|c|c|c|c|c|}
\hline \multirow[b]{2}{*}{$\begin{array}{l}\text { Pilus } \\
\text { morphology } \dagger\end{array}$} & \multirow[b]{2}{*}{$\begin{array}{l}\text { Inc } \\
\text { group }\end{array}$} & \multirow[b]{2}{*}{ Plasmid } & \multirow[b]{2}{*}{ Selection $\ddagger$} & \multirow[b]{2}{*}{$\begin{array}{c}\text { Pilus } \\
\text { synthesis§ }\end{array}$} & \multicolumn{2}{|c|}{ Transfer frequencies } & \multirow[b]{2}{*}{$\begin{array}{c}\text { Frequency ratio } \\
\text { plate/broth }\end{array}$} \\
\hline & & & & & Plate & Broth & \\
\hline Flexible & $\begin{array}{l}\text { P-3 } \\
\text { P-5 } \\
\text { P-8 } \\
\text { P-9 } \\
\text { P-9 } \\
\text { P-13 } \\
?\end{array}$ & $\begin{array}{l}\text { RIP64 } \\
\text { Rms163 } \\
\text { FP2 } \\
\text { R2 } \\
\text { TOL } \ddagger \\
\text { pMG26 } \\
\text { FP5 }\end{array}$ & $\begin{array}{l}\mathrm{Gm}_{10} \\
\mathrm{Tc}_{50} \\
\mathrm{Hg}_{12} \\
\mathrm{Cb}_{2000} \\
\mathrm{Cb}_{2000} \\
\mathrm{Sm}_{200} \\
\mathrm{Hg}_{12}\end{array}$ & $\begin{array}{l}\text { Repressed } \\
\text { Repressed } \\
\text { Repressed } \\
\text { Repressed } \\
\text { Repressed } \\
\text { Repressed } \\
\text { Repressed }\end{array}$ & $\begin{array}{l}3.7 \times 10^{-4} \\
6.8 \times 10^{-5} \\
3.4 \times 10^{-4} \\
4.9 \times 10^{-2} \\
2.6 \times 10^{-2} \\
5.2 \times 10^{-5} \\
2.9 \times 10^{-4}\end{array}$ & $\begin{array}{l}2 \cdot 1 \times 10^{-5} \\
2 \cdot 4 \times 10^{-5} \\
1 \cdot 3 \times 10^{-4} \\
1 \cdot 1 \times 10^{-4} \\
1 \cdot 4 \times 10^{-4} \\
2 \cdot 1 \times 10^{-6} \\
1.7 \times 10^{-5}\end{array}$ & $\begin{array}{c}18 \\
2 \cdot 8 \\
2 \cdot 6 \\
445 \\
186 \\
25 \\
17\end{array}$ \\
\hline Rigid & $\begin{array}{l}\text { P-1 } \\
\text { P-2 } \\
\text { P-2 } \\
\text { P-7 } \\
\text { P-10 } \\
\text { P-10 } \\
\text { P-11 }\end{array}$ & $\begin{array}{l}\text { RP1 } \\
\text { R931 } \\
\text { CAM } \\
\text { Rms148 } \\
\text { R91 } \\
\text { R91.5 } \\
\text { RP1-1 }\end{array}$ & $\begin{array}{l}\mathrm{Cb}_{2000} \\
\mathrm{Sm}_{200} \\
\mathrm{Te}_{25} \\
\mathrm{Sm}_{200} \\
\mathrm{Cb}_{500} \\
\mathrm{Cb}_{500} \\
\mathrm{Cb}_{2000}\end{array}$ & $\begin{array}{l}\text { Constitutive } \\
\text { Repressed } \\
\text { Repressed } \\
\text { Constitutive } \\
\text { Repressed } \\
\text { Constitutive } \\
\text { Repressed }\end{array}$ & $\begin{array}{l}6.8 \times 10^{-1} \\
4.3 \times 10^{-5} \\
1.0 \times 10^{-2} \\
5.6 \times 10^{-2} \\
5.2 \times 10^{-2} \\
3.0 \times 10^{0} \\
2.6 \times 10^{-1}\end{array}$ & $\begin{array}{l}8.8 \times 10^{-4} \\
9.0 \times 10^{-7} \\
9.2 \times 10^{-5} \\
8.5 \times 10^{-4} \\
2.6 \times 10^{-4} \\
6.5 \times 10^{-2} \\
1.3 \times 10^{-3}\end{array}$ & $\begin{array}{r}773 \\
48 \\
109 \\
66 \\
200 \\
46 \\
200\end{array}$ \\
\hline Unknown & P-12 & $\mathrm{R} 716$ & $\mathrm{Sm}_{200}$ & Repressed & $3.2 \times 10^{-5}$ & $1.2 \times 10^{-6}$ & 27 \\
\hline
\end{tabular}

* The host organism for all plasmids was $P$. aeruginosa strain PAO1150.1 (fla pil).

$\dagger$ The plasmids studied determined only thick flexible pili, not thick or thin flexible pili as was the case with $E$. coli K12 plasmids (Bradley, 1980a,b). There was one exception, pMG26, which had both thick and thin flexible pili. No pili were found for R716. See also Table 1.

$\ddagger \mathrm{Cb}$, carbenicillin; $\mathrm{Gm}$, gentamicin; $\mathrm{Hg}$, mercury (as chloride); Sm, streptomycin; Tc, tetracycline; Te, tellurium (as potassium tellurite). TOL was selected with carbenicillin because this example of the plasmid contained transposon Tn401 (Benson \& Shapiro, 1978), which specifies resistance to the drug. Numbers represent concentrations in $\mu \mathrm{g} \mathrm{ml}^{-1}$.

$\S$ As judged by electron microscopy (Bradley, 1980b). $\mathrm{h}^{-1}$

I Average frequencies obtained from a minimum of two experiments (see Methods), transconjugants per donor

Plasmid R716 (IncP-12) was the only example where no pili could be found in the course of an extensive search. Attempts to make a derepressed version using conventional mutagenesis with $N$-methyl- $N$ '-nitro- $N$-nitrosoguanidine failed. This result provided a 'negative control' for the experimental data described.

Group P-13 was represented by pMG26 which determined flexible pili of two different thicknesses using the temporary derepression method. The thick ones were typical flexible pili (Fig. 15). The thin ones (Fig. 16) were fairly short and about $6 \mathrm{~nm}$ in diameter. Because their thickness was similar to that of the much longer somatic pili, they were tested with antiserum to somatic pili by immune electron microscopy. No antibody adsorption was detected and there was thus no doubt that pMG26 determined two kinds of filament. Both aggregated separately and together.

FP5, though unclassified, was included because of its importance in chromosomal mapping. The temporary derepression method yielded 1-5 thick flexible non-aggregating pili on each support grid square (Fig. 17). They were similar to FP2 pili.

\section{Surface mating systems of Pseudomonas plasmids}

Table 2 compares transfer frequencies in liquid and surface environments for Pseudomonas plasmids. Results are arranged according to pilus morphological type. In order to ascertain a plasmid's degree of preference for a surface environment, the plate/broth transfer frequency ratio was calculated. A high ratio indicated a greater efficiency for a plate mating, and a lower one demonstrated that the plasmid transferred equally well in a liquid environment. The latter (universal conjugation system) was exemplified only by Rms163 (IncP-5) and FP2 (IncP-8). Thereafter, ratios increased from 17 (FP5) to a maximum of 773 (RP1) there being no obvious classes of surface mating systems as was the case with $E$. coli $\mathrm{K} 12$ plasmids (see Introduction). 


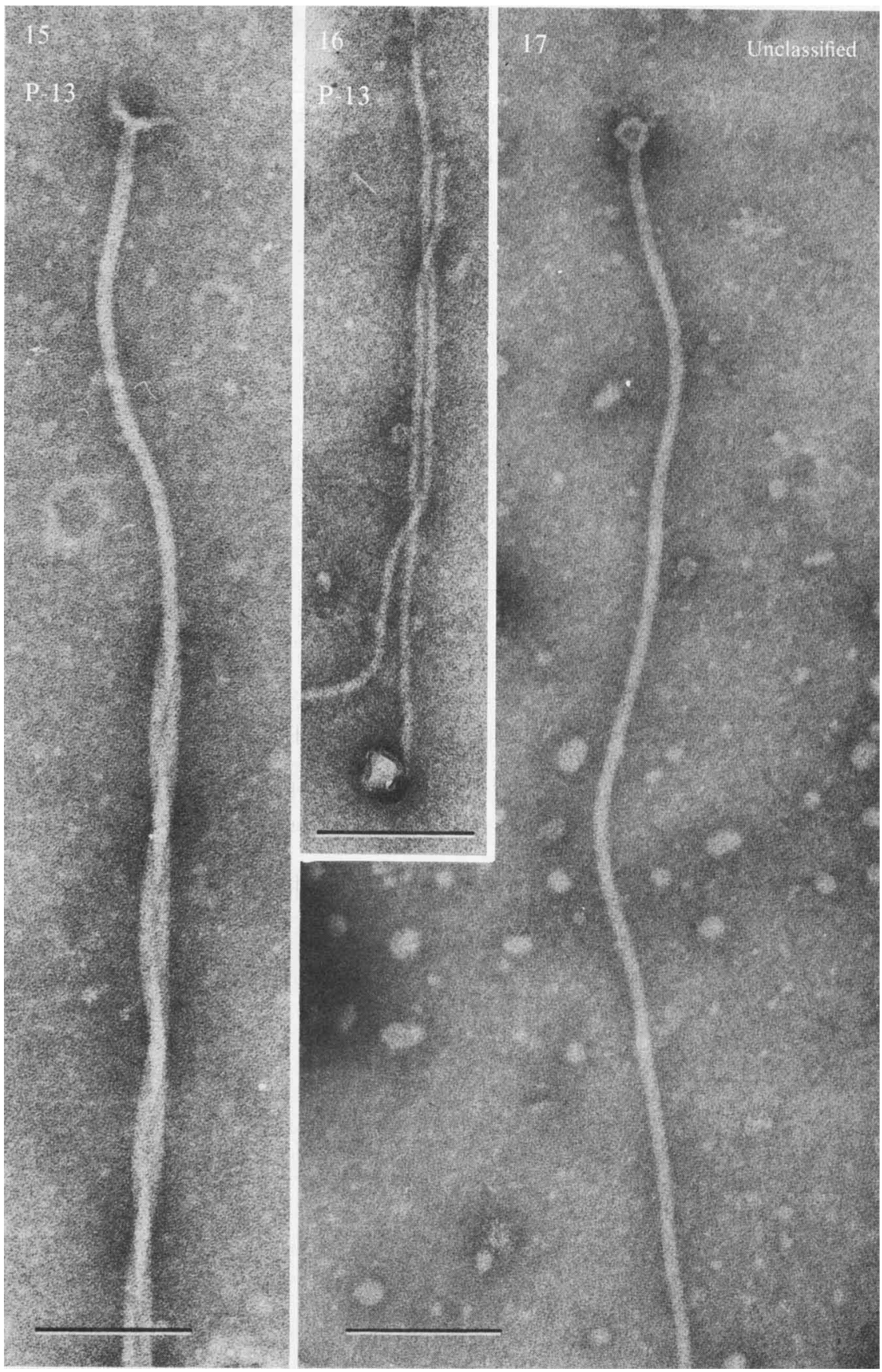

Fig. 15. Pseudomonas aeruginosa strain PAO1150.1 (pMG26) determined two kinds of pili both flexible. The figure shows the thickest $(10 \mathrm{~nm})$. The bar marker represents $100 \mathrm{~nm}$.

Fig. 16. The thin $(6 \mathrm{~nm})$ pili shown here were close to those in Fig. 15 . pMG26 belongs to group IncP13. The bar marker represents $100 \mathrm{~nm}$.

Fig. 17. The only unclassified plasmid studied was FP5 in host strain PAO1150.1. It had thick flexible pili. The bar marker represents $100 \mathrm{~nm}$. 
Plasmids with flexible pili exhibited almost as large a range of frequency ratios as did those with rigid pili.

These results also correlate the state of pilus synthesis (repressed or derepressed) with transfer frequency in the optimum environment. It was unexpected that RP1-1, which was repressed for pilus synthesis, transferred at a derepressed frequency (Bradley et al., 1980).

\section{DISCUSSION}

One of the present objectives has been to ascertain whether or not a large number of Pseudomonas plasmids determined conjugative pili like E. coli $\mathrm{K} 12$ plasmids. Only one of the fifteen examined failed to show pili. Since the exception, R716, had a very low transfer frequency, the existence of pili cannot be ruled out. Though not unexpected, the overall results show that Pseudomonas and $E$. coli conjugative pili are structurally generally similar with the same rigid and flexible forms. There is no definite evidence of a Pseudomonas or E. coli transfer system without any pili.

The comparison of surface and liquid matings has shown that only FP2 and Rms163 transferred more or less equally well in both environments (universal conjugation systems; Bradley et al., 1980). All the others were significantly better on an agar surface. However, the surface mating systems did not appear to fall into two distinct classes, surface obligatory and surface-preferred, which in $E$. coli gave plate/broth transfer frequency ratios of $>2000$ and 45 450, respectively. Pseudomonas plasmids must therefore be described as having surface preferred or universal conjugation systems. The highest ratio was 773 for RP1, about $1 / 3$ of the value for E. coli (Bradley et al., 1980), which was 2100 . It had rigid pili. Unlike E. coli K12 plasmids with rigid pili, all of which had very high plate/broth transfer frequency ratios (surface obligatory systems), some Pseudomonas plasmids with rigid pili (R91.5, R931, Rms148) had quite low ratios. These results need not reflect any fundamental differences in the mating types of Pseudomonas and E. coli K12 plasmids, but the less well-defined results with Pseudomonas may be due to interference with pilus function by the large amount of filamentous metabolic material produced by the organism.

It should be possible to correlate the state of pilus synthesis (repressed or derepressed) as revealed by electron microscopy with transfer frequency in the optimum environment. For $E$. coli $\mathrm{K} 12$ plasmids, all those derepressed for transfer (frequency $>10^{-1}$ transconjugants per donor $\mathrm{h}^{-1}$ ) determined conjugative pili constitutively (Bradley et al., 1980). Here, there was an exception, RP1-1 (Table 2); the plasmid transferred at 2.6 $\times 10^{-1}$ transconjugants per donor $\mathrm{h}^{-1}$ but few pili could be found in the electron microscope. Since only those pili detached from cells could be seen, a likely explanation is that those of RP1-1 remained attached to the cells, perhaps due to the metabolic products produced by the organism. Indeed, far fewer pili were found overall for Pseudomonas plasmids compared with E. coli plasmids. With the latter organism, not all plasmids that determined pili constitutively were derepressed for transfer (Bradley et al., 1980); the same applied to Rms 148 here. Inefficient pilus function would have this effect.

Those plasmids with low transfer frequencies provided very few pili even by the temporary derepression method (R716 had none) with the exception of pMG26. Here the temporary derepression method gave many pili indicating the presence of an efficient repressor. pMG26 also had two kinds of pilus, thick and thin flexible. A similar situation was found for E. coli $\mathrm{K} 12$ plasmids of incompatibility group $I_{1}$ (Bradley, 1983) and $I_{2}$ (Bradley \& Coetzee, 1982) though in both these cases, the thick pili were believed to be rigid and the thin ones flexible. Sufficient pili were determined by $E$. coli $\mathrm{K} 12$ plasmids to permit antiserum preparation and a survey of serological relationships among pili of different incompatibility groups (Bradley, $1980 \mathrm{~b}$ ). This is unfortunately impossible with Pseudomonas plasmids, too few pili being synthesized in most cases. It has been tacitly assumed throughout that Pseudomonas plasmid-determined pili are involved in conjugation, hence the term 'conjugative'. While this is virtually certain, it has yet to be demonstrated.

I am particularly grateful to Dr G. A. Jacoby for donating most of the plasmids and for reading the manuscript; without his help the work could not have been done. Doris Cohen and Jeannette Fleming provided excellent 
technical assistance. I also thank the Medical Research Council of Canada for financial support (Grant No. MA5608).

\section{REFERENCES}

Benson, S. \& ShaPIRo, J. (1978). TOL is a broad host range plasmid. Journal of Bacteriology 135, 278-280.

BRADLEY, D. E. (1967). Ultrastructure of bacteriophages and bacteriocins. Bacteriological Reviews 31, 230-314.

BRadley, D. E. (1972). Shortening of Pseudomonas aeruginosa pili after RNA-phage adsorption. Journal of General Microbiology 72, 303-319.

Bradley, D. E. (1974). Adsorption of bacteriophages specific for Pseudomonas aeruginosa $\mathrm{R}$ factors RP1 and R1822. Biochemical and Biophysical Research Communications 57, 893-900.

Bradley, D. E. $(1980 a)$. Determination of pili by conjugative bacterial drug resistance plasmids of incompatibility groups $\mathrm{B}, \mathrm{C}, \mathrm{H}, \mathrm{J}, \mathrm{K}, \mathrm{M}, \mathrm{V}$, and $\mathrm{X}$. Journal of Bacteriology 141, 828-837.

BRADLEY, D. E. (1980 b). Morphological and serological relationships of conjugative pili. Plasmid 4, 155169.

Bradley, D. E. (1980c). A function of Pseudomonas aeruginosa PAO pili: twitching motility. Canadian Journal of Microbiology 26, 146-154.

Bradley, D. E. (1981). Conjugative pili of plasmids in Escherichia coli $\mathrm{K}-12$ and Pseudomonas species. In Molecular Biology, Pathogenicity, and Ecology of Bacterial Plasmids, pp. 217-226. Edited by S. B. Levy, R. C. Clowes \& E. L. Koenig. New York: Plenum Publishing Corporation.

Bradley, D. E. (1983). Derepressed plasmids of incompatibility group $I_{1}$ determine two different morphological forms of pilus. Plasmid 9, 331-334.

Bradley, D. E. \& Chaudhuri, T. (1980). Characteristics and interaction with bacteriophages of pili determined by a plasmid of the $\mathrm{N}$ incompatibility group. In Plasmids and Transposons: Environmental Effects and Maintenance Mechanisms, pp. 335-342. Edited by C. Stuttard \& K. Rozee. New York: Academic Press.

Bradley, D. E. \& Coetzee, J. N. (1982). The determination of two morphologically distinct types of pilus by plasmids of incompatibility group $\mathrm{I}_{2}$. Journal of General Microbiology 128, 1923-1926.

Bradley, D. E. \& Williams, P. A. (1982). The TOL plasmid is naturally derepressed for transfer. Journal of General Microbiology 128, 3019-3024.

Bradley, D. E., Taylor, D. E. \& Cohen, D. R. (1980). Specification of surface mating systems among conjugative drug resistance plasmids in Escherichia coli K-12. Journal of Bacteriology 143, 1466-1470.

Bryan, L. E., Semaka, S. D., van den Elzen, H. M., Kinnear, J. E. \& Whitehouse, R. L. S. (1973). Characteristics of R931 and other Pseudomonas aeruginosa $\mathrm{R}$ factors. Antimicrobial Agents and Chemotherapy 3, 625-637.

Chandler, P. M. \& Krishnapillai, V. (1977). Characterization of Pseudomonas aeruginosa dere- pressed R-factors. Journal of Bacteriology 130, 596603.

Grinsted, J., Saunders, J. R., Ingram, L. C., Sykes, R. B. \& Richmond, M. H. (1972). Properties of an R factor which originated in Pseudomonas aeruginosa 1822. Journal of Bacteriology 110, 529-537.

Holloway, B. W., Krishnapillai, V. \& Stanisich, V. (1971). Pseudomonas genetics. Annual Review of Genetics 5, 425-446.

JACOBY, G. A. (1977). Classification of plasmids in Pseudomonas aeruginosa. In Microbiology-1977, pp. 119-126. Edited by D. Schlessinger. Washington, D. C.: American Society for Microbiology.

JACOBY, G. A. (1980). Plasmid determined resistance to carbenicillin and gentamycin in Pseudomonas aeruginosa. In Plasmids and Transposons: Environmental Effects and Maintenance Mechanisms, pp. 8396. Edited by C. Stuttard \& K. Rozee. New York: Academic Press.

JACOBY, G. A. \& MATTHEW, M. (1979). The distribution of $\beta$-lactamase genes on plasmids found in Pseudomonas. Plasmid 2, 41-47.

JaCOBY, G. A. \& ShaPIRo, J. A. (1977). Plasmids studied in Pseudomonas aeruginosa and other Pseudomonads. In DNA Insertion Elements, Plasmids and Episomes, pp. 639-656. Edited by A. I. Bukhari, J. A. Shapiro \& S. L. Adhya. Cold Spring Harbor: Cold Spring Harbor Laboratory.

Kawakami, Y., Mikoshiba, F., Nagasaki, S., Matsuмото, Н. \& TAZAKI, T. (1972). Prevalence of Pseudomonas aeruginosa strains possessing $\mathrm{R}$ factors in a hospital. Journal of Antibiotics 25, 607-609.

LAWN, A. M. (1967). Simple immunological labelling method for electron microscopy and its application to the study of filamentous appendages of bacteria. Nature, London 214, 1151-1152.

Loutit, J. S., Pearce, L. E. \& Marinus, M. G. (1968). Investigation of the mating system of Pseudomonas aeruginosa strain 1. I. Kinetic studies. Genetical Research 12, 29-36.

Lowbury, E. J. L., Kidson, A., Lilly, H. A., Ayliffe, G. A. \& JoNeS, R. J. (1969). Sensitivity of Pseudomonas aeruginosa to antibiotics: emergence of strains highly resistant to carbenicillin. Lancet ii, 448-452.

Matsumoto, H. \& TaZaKi, T. (1973). FP5 factor, an undescribed sex factor of Pseudomonas aeruginosa. Japanese Journal of Microbiology 17, 399-407.

Rheinwald, J. G., Chakrabarty, A. M. \& Gunsalus, I. C. (1973). A transmissible plasmid controlling camphor oxidation in Pseudomonas putida. Proceedings of the National Academy of Sciences of the United States of America 70, 885889.

Williams, P. A. \& MURRAY, K. (1974). Metabolism of benzoate and the methylbenzoates by Pseudomonas putida (arvilla) mt-2: evidence for the existence of a TOL plasmid. Journal of Bacteriology 120, 416 423. 
Witchitz, J. L. \& ChabBert, Y. A. (1971). Résistance transférable à la gentamicine. I. Expression du caractère de résistance. Annales de l'Institut Pasteur 121, 733-742.

Witchitz, J. L. \& Gerbaud, G. R. (1972). Classification des plasmides conférant la résistance a la gentamicine. Annales de l'Institut Pasteur 123, 333339.

Wong, C. L. \& DunN, N. W. (1974). Transmissible plasmid coding for the degradation of benzoate and $m$-toluate in Pseudomonas arvilla $\mathrm{mt}-2$. Genetical Research 23, 227-232. 